\title{
Impact of the Danube River on the groundwater dynamics in the Kozloduy Lowland
}

\author{
Peter Gerginov \\ Geological Institute, Bulgarian Academy of Sciences, Acad. G. Bonchev Str., Bl. 24, 1113 Sofia, Bulgaria; \\ e-mail:p.gerginov@mail.bg.
}

(Accepted in revised form: October 2017)

\begin{abstract}
Intense groundwater flow in the Kozloduy Lowland is related to the formed layered aquifer on the contemporary Danube River terrace. The main factors affecting the groundwater regime are fluctuations of the Danube River, water influx from the south and the recharge as a part of the rainfalls in the area. The drainage system in the central part of the lowland affects the water levels and creates a widespread depression. This forms a disturbed groundwater regime in the area. The impacts of the Danube River for a six-year period (from 2007 to 2012) have been estimated. The groundwater balance elements were analyzed, based on transient numerical model of the lowland. Fluctuations of the groundwater levels are the most significant close to the river at a distance of 300-400 m, reaching as much as $1000 \mathrm{~m}$ in the lowland. Oscillation's amplitude of groundwater levels gradually decreases with distance from the river and as a result of the drainage system abstraction. There is relation between the water stages in the river and the intensity of the drainage flow.
\end{abstract}

Gerginov, P. 2017. Impact of the Danube River on the groundwater dynamics in the Kozloduy Lowland. Geologica Balcanica 46 (2), 33-39.

Keywords: hydrogeology, groundwater dynamics, Kozloduy Lowland, Danube River, Bulgaria.

\section{INTRODUCTION}

The Danube River has a significant impact on the groundwater dynamics, as well as on the exploitation and security of the facilities in the Kozloduy Lowland. Depending on water stages in the river, it has a feeding or drainage effect on the groundwater in the area. During high waters, in natural conditions, it floods wide parts of the lowland, and the water drains later for long periods. The lowland is protected by a dike, along the river, for flooding prevention. However, the river causes a rise in groundwater levels, which affects the Quaternary aquifer complex.

A number of studies have been carried out to assess the possible maximum water levels during the design and exploitation of the nuclear power plant located in the center of the lowland. Possible impacts on the nuclear plant, such as destruction of hydrotechnical facilities, both acting and designed, have been evaluated. These studies are related to setting different scenarios that describe specific events (Yotov, 2011; Evstatiev et al., 2012).

The water balance elements were evaluated based on previous studies (Spasov, 1980; Reports 2003, 2009) and recent investigations in the area.
The purpose of this paper is to evaluate the impact of the hydrological cycle of the Danube River on the groundwater regime in the lowland based on the transient numerical model.

\section{STUDY AREA DESCRIPTION}

The study area is located in Northwest Bulgaria and coincides with the boundaries of the Kozloduy Lowland. It covers the lowest part of the contemporary terraces of the Danube River. The Kozloduy Lowland is situated between the Danube River to the north and the Ogosta River valley to the east-southeast. It rises smoothly to the west towards the Zlatiya Plateau. To the south, the lowland ends with a high part coinciding with the surface and underground watershed. South boundary of the study area is the Harlets-Kozloduy road (Fig. 1). The delineated boundary represents the contact between the alluvial materials and the older river terraces covered by layered loess complex.

The study area $\left(38 \mathrm{~km}^{2}\right)$ corresponds to the geological and lithological boundaries of the Kozloduy Lowland (Filipov et al., 1989). The active groundwater flow in the valley is related to the formed alluvial 


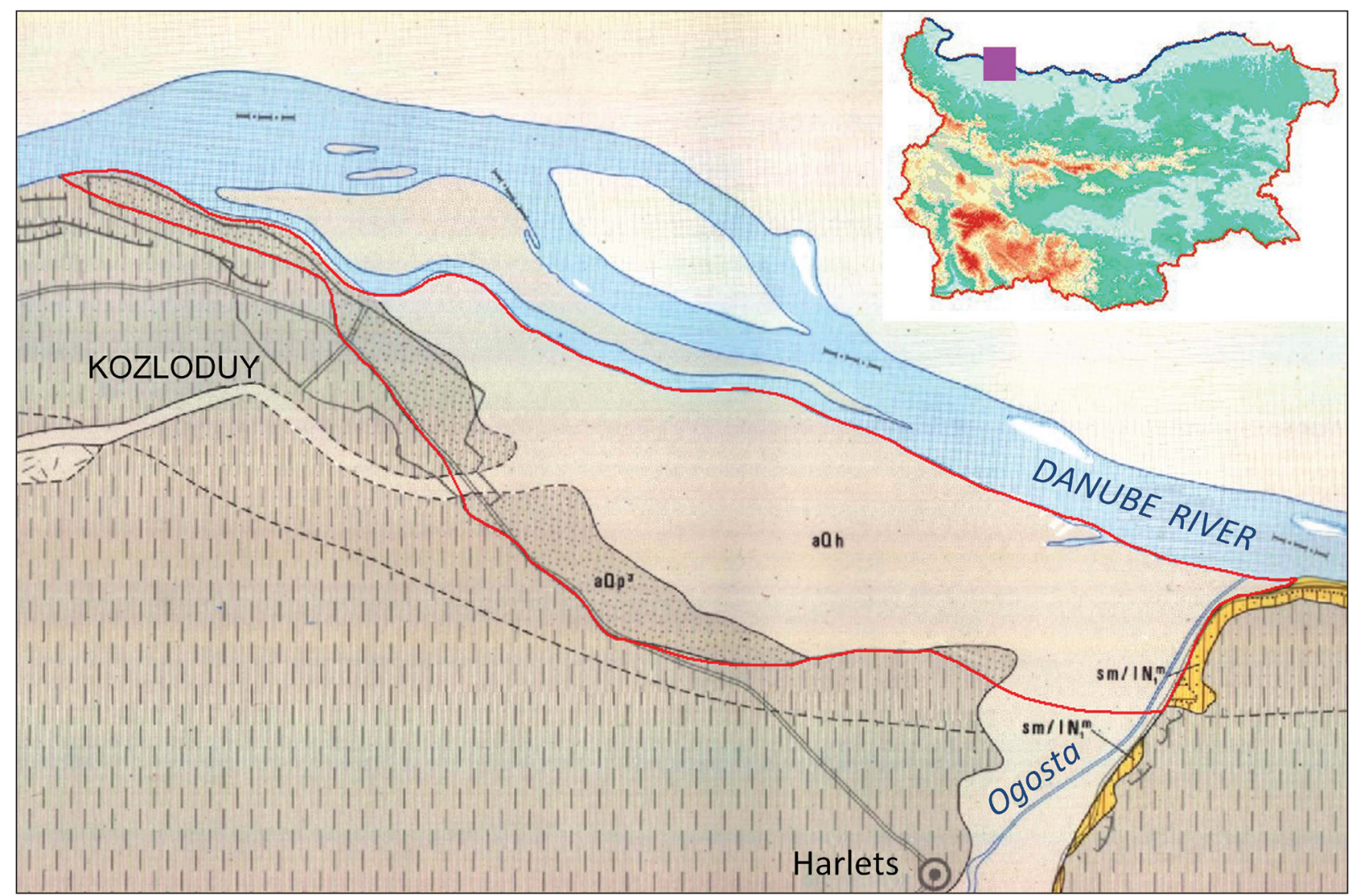

Fig. 1. Location and boundary of the study area on the geological map of Bulgaria in scale 1:100 000, Kozloduy map sheet (after Filipov et al., 1989). aQh - deluvial materials (clay-sandy and loess materials); $\mathrm{aQ}_{\mathrm{p}}{ }^{3}$ - alluvial materials (gravel, sands and clays); $\mathrm{sm} / 1 \mathrm{~N}_{1}{ }^{\mathrm{m}}$ - Smirnenski Formation (sandstones and sandy limestones).

aquifer complex of the river floodplain. The aquifer is built up of sands and gravels covered with silty clays and sandy clays. The total thickness of the deposits reaches $20 \mathrm{~m}$. The conductivity of the alluvial aquifer has been investigated in previous studies and shows a wide range of values. Possible reason for that wide range is the different thicknesses of lithological units, with gravel being the most important for the higher values of transmissivity.

Coverage at the top of the section is related to the infiltration of rainwater through the alluvial deposits. From hydrogeological point of view, it represents the unsaturated zone, with thickness of 10-15 m, consisting of sandy to clayey loess. Hydraulic conductivity values of the loess cover vary from $0.1 \mathrm{~m} / \mathrm{d}$ to $2.0 \mathrm{~m} / \mathrm{d}$, depending on the presence of loamy or sandy components in the sediments.

The main direction of groundwater flow in the Kozloduy Lowland is from the southwest to the northeast. Hydraulic flow gradients range from $0.03-0.035$ to the south of the area (the high terraces of the Danube River) to 0.0001 in the north part, next to the river. Water levels of the shallow groundwater range from 27.00 to $28.00 \mathrm{~m}$ above sea level (asl) in the southern part of the area. They gradually decrease towards the river down to $24.30 \mathrm{~m}$ asl as multiannual value.

The hydrologic regime of the Danube River is formed from mixed rain-snow feeding, more strongly in the upper and middle Danube areas and less pronounced in the lower parts. The high water of the river is common in April and May. During the months of July to November, despite the general trend of water decline, high waves vary in intensity and magnitude due to precipitation. Autumn low flow is observed between October and November, with the most pronounced minimum in October. Low water levels are also recorded during the winter, in January and February, during significant colds.

The reported precipitation in the lowland is unevenly distributed throughout the year. Maximum of the rainfall is in May-June, with secondary maximum in November. The mean annual rainfall in the central part of the Kozloduy Valley for the period 1998-2011 is $420 \mathrm{~mm}$, which is one of the lowest in the country. The measurements show a significant reduction in the rainfall amount over the indicated period, compared to previous periods. For 1967-1986, the average rainfall was $595 \mathrm{~mm}$ on average. Part of the precipitated water 
infiltrates in depth, reaches the aquifer and influences its water balance. Groundwater levels vary in respect to the input of the recharge water and hydrological regime in the Danube River.

The hydrodynamics of the Kozloduy Lowland is also influenced by the work of a drainage system located in its central part. Channels take the incoming high water from the river, rainfalls and groundwater flow from the south. Drainage channels are situated in west-east direction, set at an absolute elevation of $+24.50 \mathrm{~m}$ asl.

\section{METHODS AND DATA}

Hydrodynamics of the alluvial layered aquifer was simulated by using MODFLOW as a module in GMS 6.0 (Groundwater Modeling System). Calculation procedure solves the partial differential equation describing the three-dimensional groundwater flow. The solution uses finite difference method, taking into account the boundary and initial conditions.

For the purposes of this study, regional transient model was constructed. The model area falls into the outline of the Kozloduy Lowland. It is $17 \mathrm{~km}$ long in $\mathrm{W}-\mathrm{E}$ direction and $4 \mathrm{~km}$ wide in N-S direction (Fig. 2). Cross-sectional pattern is one-layered. The active thickness of the model layer ranges from $24 \mathrm{~m}$ to $30 \mathrm{~m}$, with grid size of $60 \times 60 \mathrm{~m}$. Transmissivity values in the area vary from $100 \mathrm{~m}^{2} / \mathrm{d}$ to $1500 \mathrm{~m}^{2} / \mathrm{d}$. The specific yield of the medium was set to 0.06 for the entire area.

Northern boundary of the area is the Danube River. It was set as Dirichlet boundary condition (first order) in the model calculations. The southern boundary represents the contact between the lower parts of the low- land and the slope to the loess plateau. It was set as head dependent boundary. Drainage system operates in the central part of the model area, according to its real geometry. Groundwater level observations in the south parts of the area were used for model calibration. Due to their significant distance from the river $(3.7 \mathrm{~km})$, they are not affected by the hydrological regime of the river. Aquifer water levels at observation points have a direct connection with precipitation and groundwater inflow from the south.

Time-series for the Danube River stages for a period of six years, from 2007 to 2012, were used in the study (Fig. 3). Percentage of rainfall sums at equal tenday intervals was imported as initial boundary condition in the model.

Available precipitation values cover the period from 2007 to 2011 (Fig. 4).

\section{RESULTS}

Model solutions give an idea of some basic dependencies between the water balance elements of groundwater in the Kozloduy Lowland. Figure 5 presents graphically the relationship between the inflow from the Danube River and the drainage system outflow.

Calculated maximum discharge values from the drainage system occur during the high river stages. The response of the drainage system is almost instantaneous, in respect to the rise of the water stages in the river. For the period under consideration (2007-2012), the maximum water quantities incoming from the river are 460 1/s. Drains extract up to 320 l/s water.

The relationship between fluctuations of the Danube River and the precipitation in the area outlines the

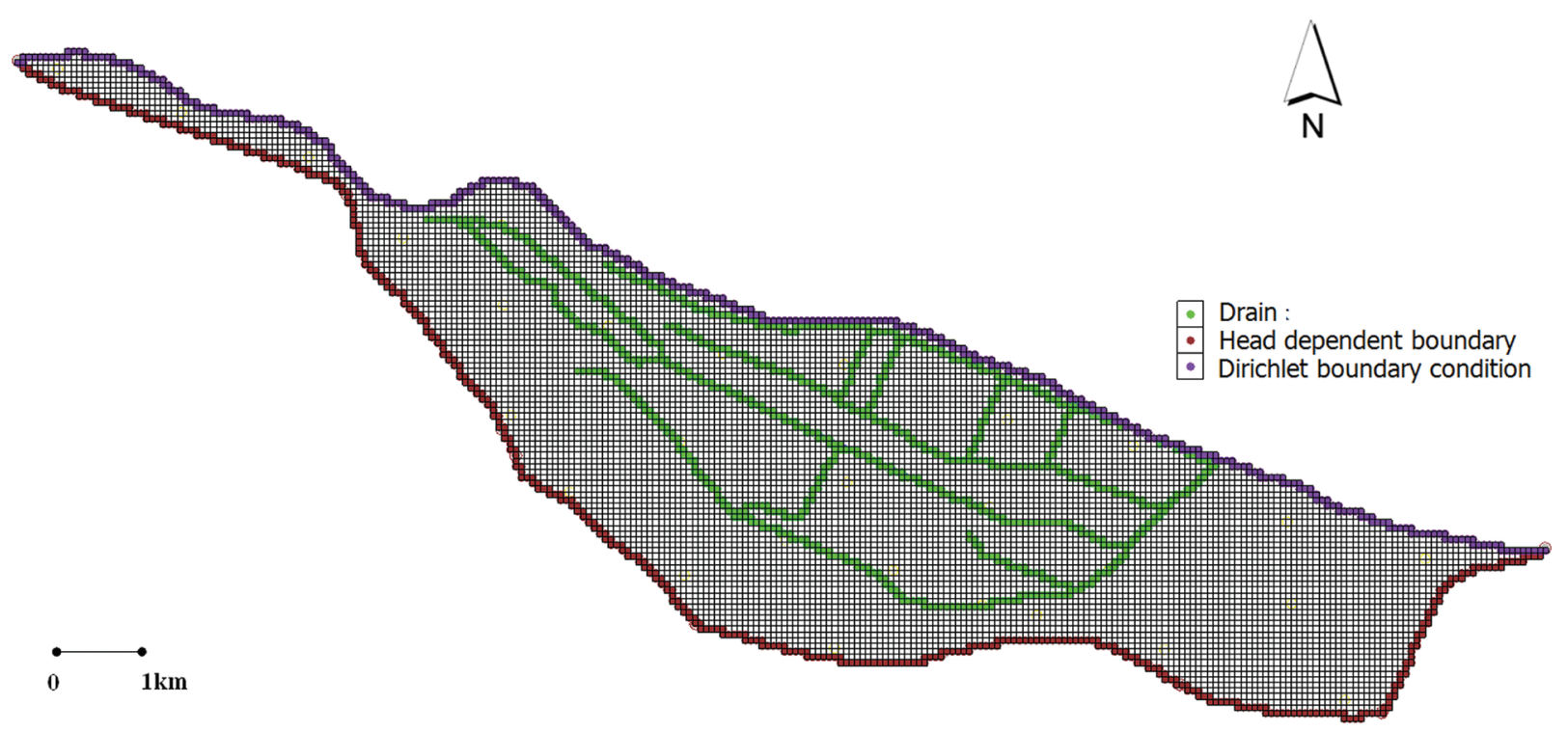

Fig. 2. Conceptual model of the Kozloduy Lowland. 
absence of a clear trend in the two processes. It confirms that the feeding of the Danube River takes place in the upper and the middle stream and less locally.

Drainage system works most intensively at high water in the Danube River, according to the model results. When the groundwater levels are lower than the drainage channels' elevations, the river drains the groundwater. In other cases, the groundwater is diverted to a variable extent from the drainage and the river (Fig. 6). The average flow rate values of the

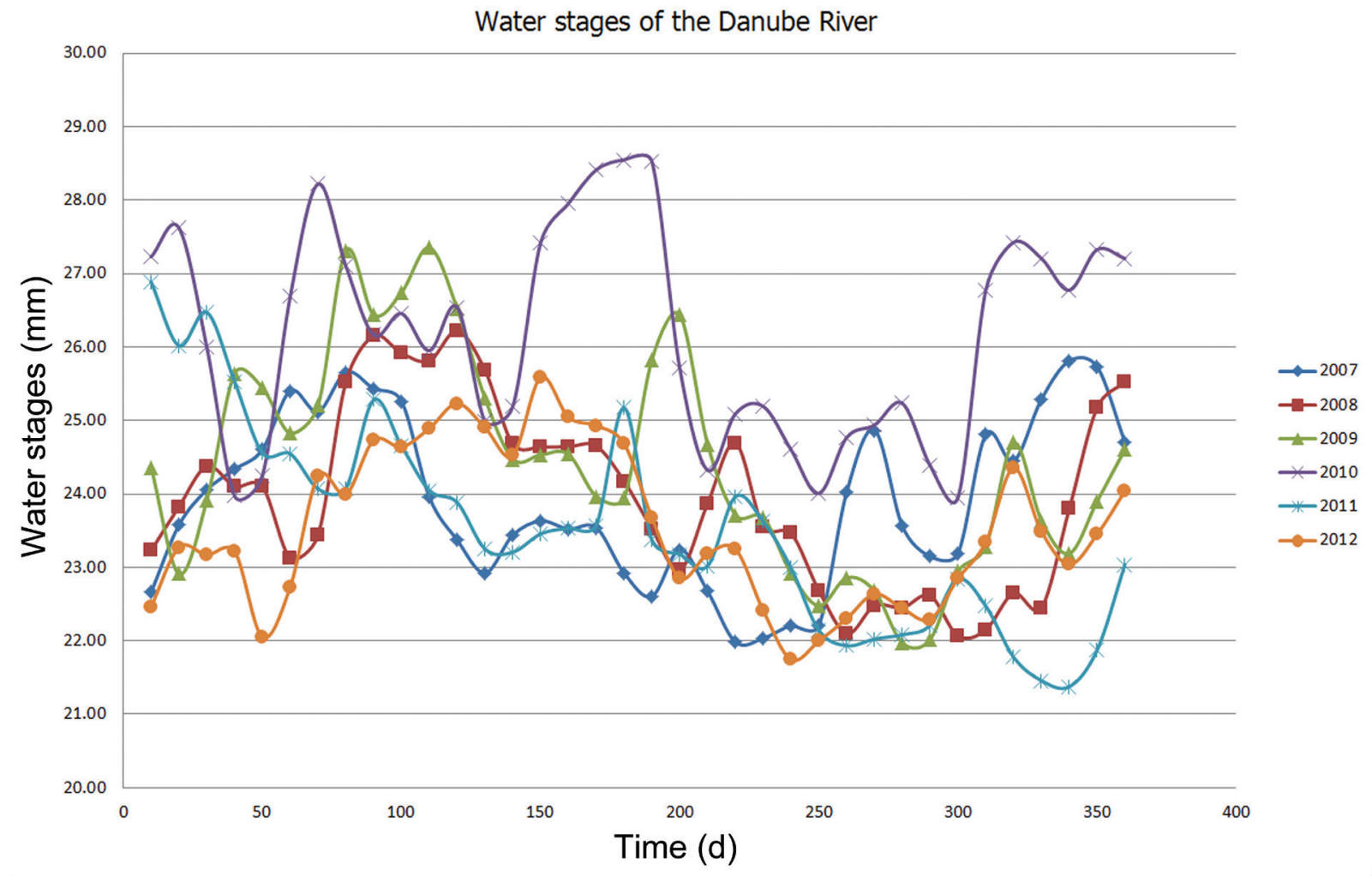

Fig. 3. Water stages of the Danube River (averaged for ten days) at the BPS-1 monitoring station for the period 2007-2012.

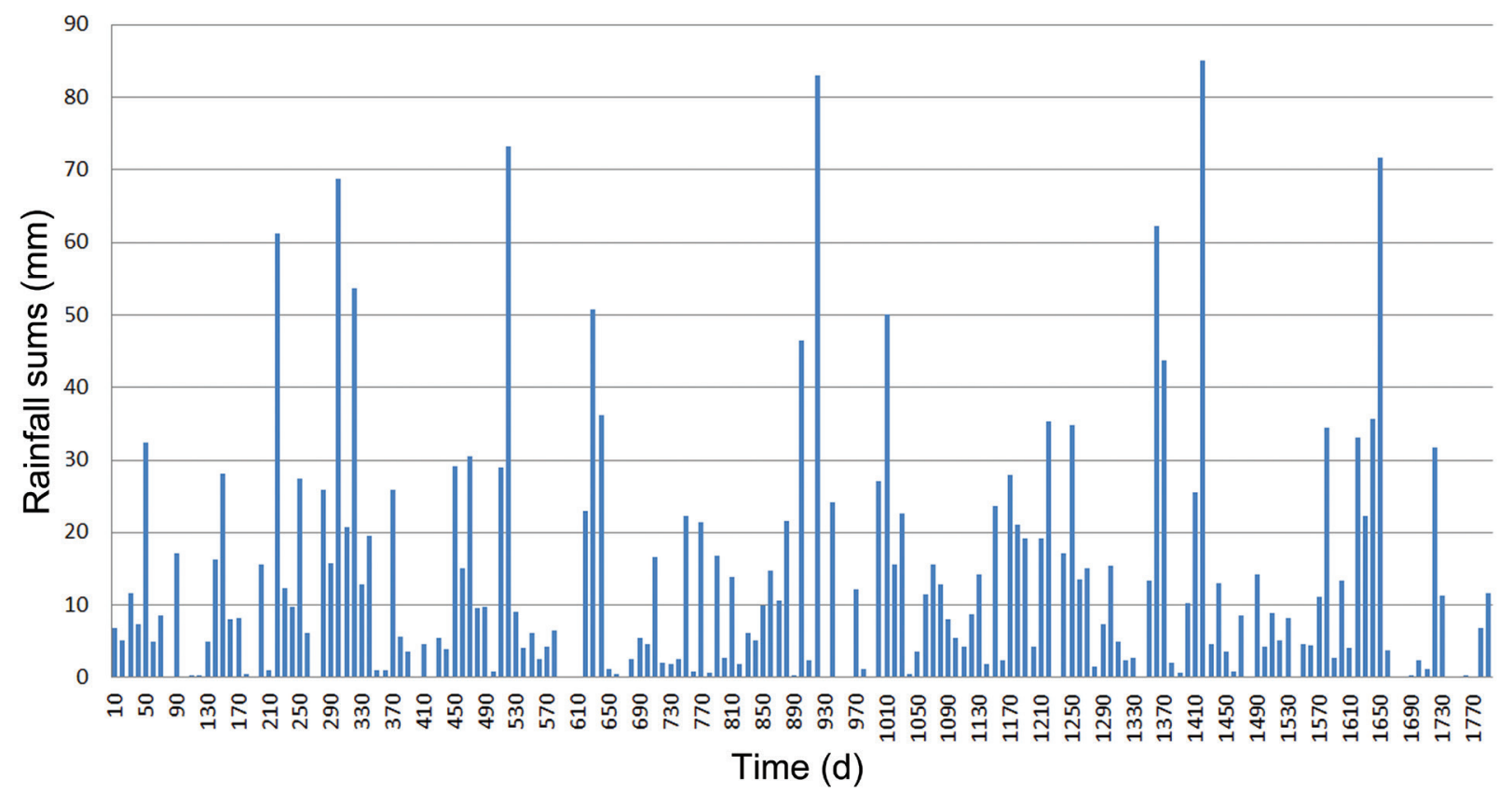

Fig. 4. Precipitation in the Kozloduy Lowland for the period 2007-2011. 


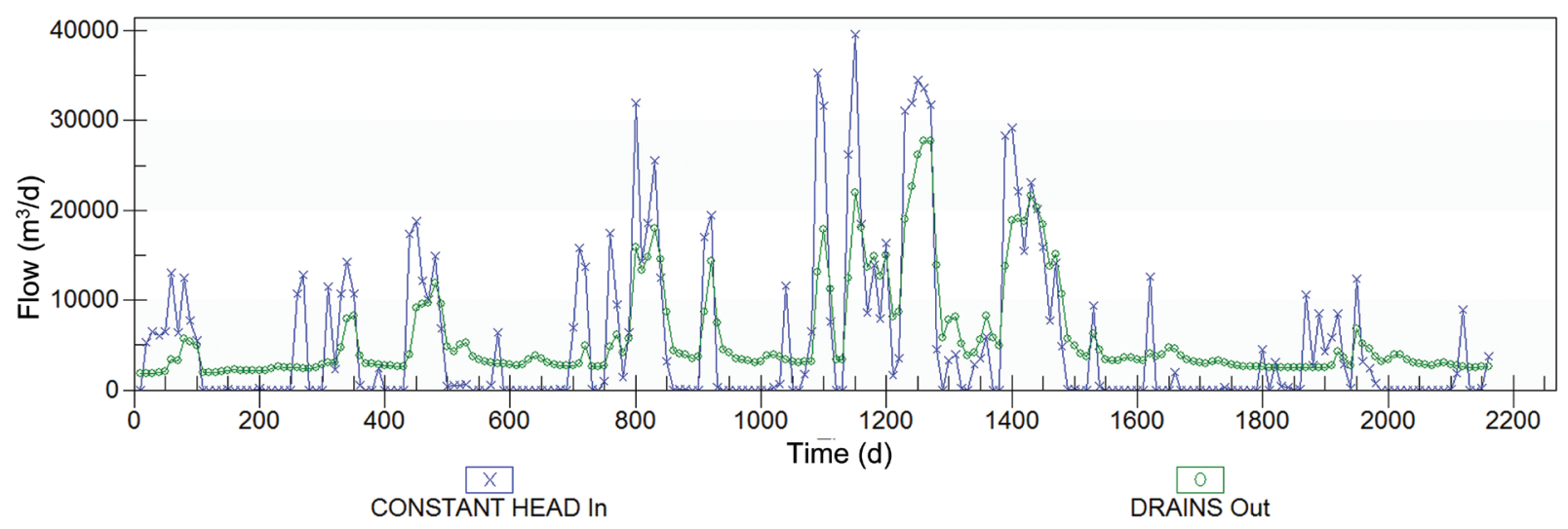

Fig. 5. Dependence between water inflow from the Danube River versus water extraction by the drainage system $\left(\mathrm{m}^{3} / \mathrm{d}\right)$.

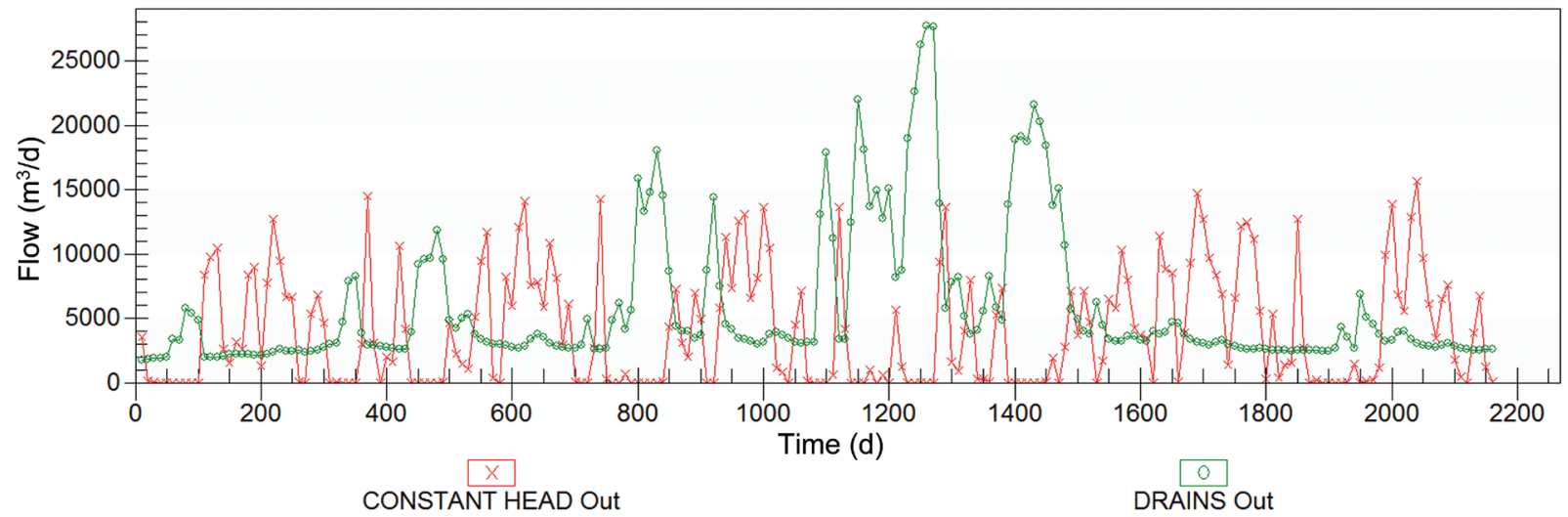

Fig. 6. Dependence between the drained quantities into the Danube River and the drainage system extraction $\left(\mathrm{m}^{3} / \mathrm{d}\right)$.

drainage system are due to groundwater inflow from the south boundary and recharge from precipitation in the area.

The impact of the Danube River was determined by introducing artificial observation points along profiles perpendicular to the river. Significant fluctuations in groundwater levels near the river are a result of higher water levels in the river. Gradually, that influence attenuates and outlines maximum limit of reach of the river impact to the groundwater of the Kozloduy Lowland (Fig. 7).

Changes in groundwater levels are the most significant close to the river at distance of 300-400 m. Maximum impact is predicted up to $1000 \mathrm{~m}$, for the period 2007-2012. The amplitude of fluctuations is gradually decreasing in the lowlands away from the river, and it is influenced by the drainage channels. There is also a corresponding delay in the response of the shallow aquifers. Variations of the groundwater levels are smoother, with lower amplitude.

\section{CONCLUSION}

Groundwater levels in the Kozloduy Lowland are affected by the hydrological regime of the Danube River, groundwater flow from the south and recharge from rainfalls. The groundwater regime of the Kozloduy Lowland was studied based on the transient model. Calculated maximums of water extracted by the drainage system coincide with the high river stages. Drainage system reacts almost instantaneously with elevation of water stages in the river. For the period between 2007 and 2012, the maximum water quantities incoming from the river to the lowland are $460 \mathrm{l} / \mathrm{s}$. Drains extract up to $320 \mathrm{l} / \mathrm{s}$. Impact of the water stage in the Danube River is most strongly expressed in the riverside zone (300-400 m wide and up to $1000 \mathrm{~m}$ inside the lowland) during high levels in the river. The drainage system located in the central part of the lowland controls the effect on the groundwater level fluctuations and drains the lowest parts of the area. 


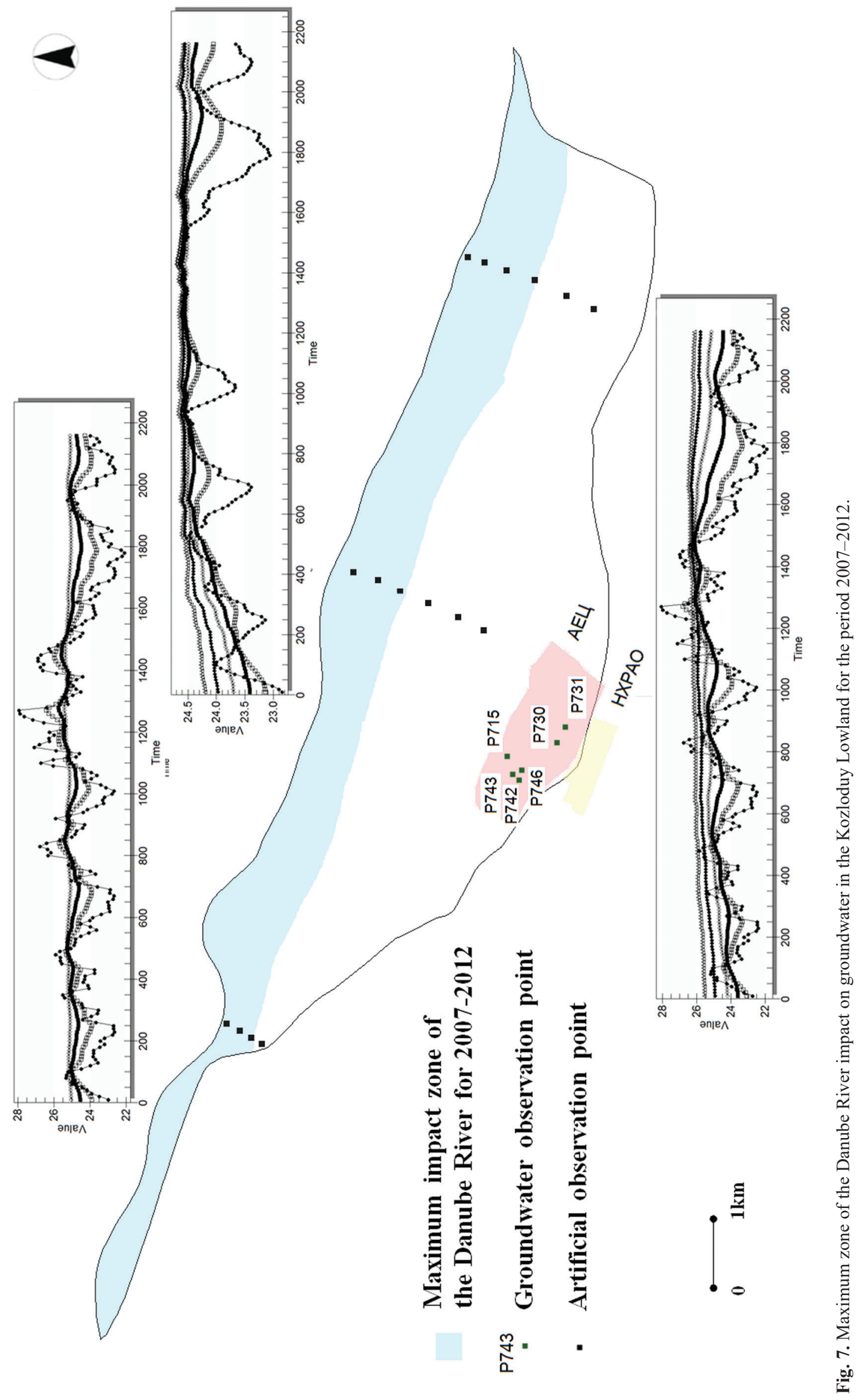




\section{REFERENCES}

Evstatiev, D., Evlogiev, Y., Yotov, Y. 2012. Prediction of possible changes in the hydrogeological conditions of the lower part of the Radiana site in case of unfavorable hydrological, hydrotechnical and climatic conditions and assessment of erosion and flooding threat. Geological Institute "Str. Dimitrov", Bulgarian Academy of Sciences, Sofia (in Bulgarian, unpublished report).

Filipov, L., Koyumdzhieva, E., Popov, N. 1989. Geological map of the Republic of Bulgaria 1:100 000, Kozloduy map sheet. Committee on Geology, Company for Geophysical surveys and Geological Mapping, Sofia.

Report of Additional Engineering and Geological Studies. 2003. Kozloduy NPP, unpublished report (in Bulgarian).

Report on local weather in the Kozloduy area. 2009. Consor- tium "MCE", unpublished report (in Bulgarian).

Spasov, V. 1980. Report on task 39.4.1. "Hydrogeological research for determination of balance elements of the groundwater and filtration properties in the Danube lowlands within the reach of Nikopol-Turnu Magurele". Complex studies of the Danube River in the Bulgarian section. Kozloduy Lowland. Geological Institute "Str. Dimitrov", Bulgarian Academy of Sciences, Sofia (in Bulgarian, unpublished).

Yotov, I. 2011. Report on the task "Assessment of the change of ground water level at the Radiana site at maximum elevation at the level of the Danube". Geological Institute "Str. Dimitrov", Bulgarian Academy of Sciences, Sofia (in Bulgarian, unpublished). 